\title{
Investigation into Current Condition of the Cultural Capital of Chinese EFL Teachers in the Universities of Sichuan Province in China*
}

\author{
Lina Guan \\ Foreign Language Department, Sichuan University of Arts and Sciences, Dazhou City, Sichuan Province, China
}

\begin{abstract}
Pierre Bourdieu put forward famous Cultural Capital Theory, which includes the embodied cultural capital, the objective cultural capital and the institutionalized cultural capital. This article investigated the current condition of the cultural capital of EFL teachers coming from the four universities of Sichuan Province in China from three aspects of the cultural capital: the embodied cultural capital, the objective cultural capital and the institutionalized cultural capital. Results show many EFL teachers are difficult to accumulate their embodied cultural capital, objective cultural capital and institutionalized cultural capital because of the diverse requirements of different universities and the diverse English levels of different students.
\end{abstract}

Index Terms - the objective cultural capital, the institutionalized cultural capital, the embodied cultural capital, teachers' burnout

\section{INTRODUCTION FOREWORD}

Recently with the development of Internet, MOOC (2014), which means "Massive and Opening Internet Lessons", has been widely used in EFL teaching in China. The advantages of MOOC are opening, productivity and fragmentation, which can change students' studying ways and EFL teachers' teaching ways. It means EFL teachers should adjust the teaching objects, the teaching content and the teaching evaluation and it brings more responsibilities and higher requirement to EFL teachers. In order to guide students to fit the reform of teaching methods, EFL teachers should exert the professional expertise and subjective initiative.

\section{BRief Introduction to Cultural CAPITAL Theory}

Pieer Bourdieu (2017), French sociologist, put forward Theory of Cultural Capital at the end of 1960s and the early of 1970s and published The Forms of Capital in 1986. He suggested the capital should fall into three categories: the economic capital v the cultural capital and the social capital. The cultural capital among them consists of the embodied cultural capital, the objective cultural capital and the institutionalized cultural capital. The embodied cultural capital includes individual cultural quality and individualizes character that individual persons should accumulate for the long time. The objective cultural capital includes papers、works、 personal teaching diaries and books written by the writers. It needs the assist of the economic capital and it means the personal possess of the cultural product, which features inheritance and development. The institutionalized cultural capital includes the ways to conform the legalization of the embodied cultural capital, such as certificates of degree、 diplomas、 award certificates and certificates of title, etc, which is the recognition and guarantee of personal legalized cultural capital and which will not change according to the will of individual cultural capital. These three kinds of capital can be measured and the persons who own more total cultural capital than the others can have the dominant positions in the society.

Now many Chinese scholars research Chinese EFL teachers' education and development from the viewpoint of Cultural Capital Theory. For example, Li qingling (2010), explored the outlet problems of Chinese intellectuals; Li jingqi (2012) probed change of the social status of Chinese teachers in rural schools; Zhang zhihao (2016) investigated Chinese ideological and political teachers' development in Chinese private universities. Now there are many EFL teachers in Chinese colleges and universities but few scholars research how much they can own their cultural capital and research how it will affect development of EFL teachers. This article puts the focus on the investigation of the current condition of Chinese EFL teachers' cultural capital and tries to get to know how it influences EFL teachers' self-development and classroom teaching.

\section{Research PRocedures AND MethodS}

\section{A. Purpose of Research}

\footnotetext{
${ }^{*}$ Funded by Teachers Education Research Project of Sichuan University of Arts and Sciences (2018JJ005Y)
} 
This article investigated Chinese EFL teachers' current condition of the cultural capital from three aspects of the embodied cultural capital, the objective cultural capital and the institutionalized cultural capital. The teachers investigated are from the following Chinese universities :Sichuan University of Arts and Sciences、West of China Normal University、Southwest Petroleum University and North Sichuan Medical College, all of which are located in Sichuan province in China.

\section{B. Research Methods}

Research methods include the interview for some Chinese EFL teachers and questionnaires survey. In the first stage the writer interviewed ten EFL teachers for an hour and put forward the following questions: 1. How do you think of the change of college English teaching methods? 2. What's your current teaching wish? 3. How do you improve your teaching quality? 4. How do you improve your English proficiency in your spare time? In the second stage EFL teachers investigated will finish one questionnaire and the questionnaire is adapted according to the ones written by Wang Nan (2017) and Sun Yuan (2013)which were related to the relevant content of college English teachers' professional development. The questionnaire includes three aspects of the cultural capital: the embodied cultural capital, the objective cultural capital and the institutionalized cultural capital. Every aspect consists of the specific choices varying from three items to eight items.

\section{Research Objects}

Research objects for interviewing are ten college English teachers chosen from Sichuan University of Arts and Sciences and West of China Normal University. Among of them four teachers are over 45 years old and four teachers are between 45 years old and 35 years old and two teachers are under the age of 35 years old. The time for interviewing lasts one hour and ten teachers are teacher A, teacher B, teacher C, teacher D , teacher E , teacher $F$, teacher $G$, teacher $\mathrm{H}$, teacher I and teacher J. Ninety EFL teacher from four universities including Sichuan University of Arts and Sciences、West of China Normal University、Southwest Petroleum University and North Sichuan Medical College filled in ninety questionnaires via E-mails and there were eighty seven valid questionnaires.

\section{RECORDING AND ANALYSIS OF RESUltS FOR INTERVIEWING TEN COLLEGE ENGLISH TEACHERS}

Question one: How do you think of the change of college English teaching methods? Question two: What's your current teaching wish?

Teacher A said: "With the development of Internet students have many ways to acquire knowledge and they will not regard their teachers as the authority of knowledge. Many students had learned English for more than ten years before they entered universities so the purpose of English teaching in Chinese universities is to combine many teaching models to assist and help students study, improve their studying interest and help them solve the difficulties in their studies. Now I have four English lessons for every class and teaching time in the class is short and teaching materials are limited. I will assign students some studying tasks after school and supervise and urge them to finish. I think under the current social condition EFL teachers should change teachers' roles." Teacher B said“'In my English class I think the focus is to make students keep their interest to study English then students will study actively. But it's hard to achieve it. In this term I teach five different classes. Three classes are the advanced classes and two classes are the adjustment classes. Students' English levels are quite different among different classes. When I teach in the adjustment classes, I often help students review some English grammar which they didn't learn well in their senior schools and most students always keep silent in the classes and most of them can't finish the studying tasks after school. I have to use the traditional teaching methods to teach them, which means the I still guide the whole teaching in the class. Although I know English teachers should change their teaching models, it still depends on the specific students' English levels. My teaching wish is to teach my students well and finish the scientific research tasks assigned by my university." Teacher F said "Now my university not only demands teachers to improve teaching quality but also demand every teacher should finish some scientific tasks within the required time otherwise teachers will have deductions to wages. I didn't finish my scientific research tasks last year and I am under great pressure now. I hope the university can reduce some amount of the scientific research tasks for teachers, after all most teachers' main purpose is to teach their students well and if they have free time they can choose to do some research jobs."

Question three: How do you improve your teaching quality? Question four: How do you improve your English proficiency in your spare time?

Teacher C said "My university puts forward the major tasks for English teachers who should help students pass examinations of CET Four and CET Six, and if the ratio to pass examinations is too low the teacher will be blamed by the leaders and will feel lose face. Although we want to give students more autonomous studying, our English teaching still focus on the practice of English grammar and English vocabularies studying because it's useful to pass the examinations." Teacher E said "In our college the dean summons EFL teachers to have English teaching and research meetings sometimes and holds the observation and learning teaching activities. In summer vacation and winter vacation EFL teachers can attend English training classes held by the publishing houses and can listen to some English lectures given by some experts in this field. I think it's still not enough for English teachers to improve their teaching quality. In Chinese universities and colleges EFL teachers are often under great pressure because of the demanding for the higher 
professional titles. One male teacher among sixty-one EFL teachers in my college has got the doctor degree and all the female teachers don't get the doctor degree." Teacher E said "My major is English Curriculum and English Teaching Methods Research and this term I have undertaken a teaching research project. I have made some research and interviewed some teachers and their students in some classes, hoping to find the valuable topic to research. It will last long time to do it and I haven't done it continuously because of my busy teaching job because I have eighteen lessons in one. I hope we don't need to teach so many lessons every week then we can have time to research and improve the teaching methods to teach students well and students can also learn more from teachers." Teacher G said "We should finish the research tasks assigned by our university every year. As a young teacher I have a lot of teaching task to finish every week and at the same time I need to write the academic paper and prepare the examination for the doctor degree. So I don't spend much time in my teaching and often teach my students in the traditional teaching ways."

The results of interviewing reveal that most EFL teachers know they should change the traditional teaching models in which teachers dominate and guide the class teaching and students only listen to teachers' teaching passively. Because of different teaching requirements of different universities and diverse students' English levels, most teachers don't spend much time and energy studying and trying the new teaching models in their classes and still adopt the traditional teaching models. Teaching models are static、monotonously and doctrinal and EFL teachers also can't develop their subjective initiative. Because of their busy workload the teachers can't spare more time and energy to study and get further training, so the teachers can't write enough academic papers, which can make them not get the higher professional titles. It's hard for them to get embodied cultural capital, which will influence the forming of the objective cultural capital and institutionalized cultural capital.

\section{RESUlTS OF QUESTIONNAIRES AND ANALYSIS}

TABLE I.

EFL TEACHERS' BRIEF INTRODUCTION WHO HAVE FILLED IN THE QUESTIONNAIRES

\begin{tabular}{|l|l|l|l|l|l|l|}
\hline age & male & female & professors & associate professors & lecturers & teaching assistants \\
\hline between 20 and 30 years old & 12 & 18 & 0 & 0 & 1 & 5 \\
\hline between 30 and 40 years old & 11 & 20 & 0 & 7 & 18 \\
\hline between 40 and 50 years old & 7 & 8 & 6 & 16 & 5 \\
\hline between 50 and 60 years old & 5 & 6 & 3 & 7 & 0 \\
\hline
\end{tabular}

TABLE II.

INVESTIGATION OF THE EMBODIED CULTURAL CAPITAL

\begin{tabular}{|l|l|l|l|l|l|}
\hline items of questionnaire & $\begin{array}{l}\text { knowing it } \\
\text { quite well( } \%)\end{array}$ & $\begin{array}{l}\text { knowing much } \\
\text { about it }(\%)\end{array}$ & $\begin{array}{l}\text { knowing some } \\
\text { about it }(\%)\end{array}$ & $\begin{array}{l}\text { knowing a little } \\
\text { about it }(\%)\end{array}$ & $\begin{array}{l}\text { not knowing at } \\
\text { all about it }(\%)\end{array}$ \\
\hline $\begin{array}{l}\text { 1.cultural background knowledge of } \\
\text { English-speaking countries }\end{array}$ & 68 & 20 & 12 & 0 & 0 \\
\hline 2.English- teaching capability & 65 & 25 & 10 & 0 & 0 \\
\hline $\begin{array}{l}\text { 3.the adjustment for reforms of college English } \\
\text { teaching models }\end{array}$ & 59 & 20 & 21 & 0 & 0 \\
\hline 4.good English-writing capability about the ways of college & 36 & 30 & 12 & 0 & 0 \\
\hline $\begin{array}{l}\text { 5.knowing well about } \\
\text { English teaching reform }\end{array}$ & 40 & 20 & 4 & 0 \\
\hline $\begin{array}{l}\text { 6.good spoken-English communication ability } \\
\text { 7.knowing well about the knowledge of } \\
\text { pedagogy and psychology }\end{array}$ & 39 & 35 & 16 & 10 & 0 \\
\hline $\begin{array}{l}\text { 8.knowing well about English pedagogical } \\
\text { content knowledge }\end{array}$ & 30 & 28 & 34 & 9 & 0 \\
\hline
\end{tabular}

Results of questionnaires above show most EFL teachers under investigation have rich English professional knowledge and teaching experience and have excellent capability for writing and communication in English. They know American and British culture quite well. Most teachers believe English teaching reform is coming and now the teaching concepts and teaching models for college English are quite different from before. Some teachers also think they don't know the knowledge of pedagogy and psychology quite well because they didn't study the major in English Curriculum and English Teaching Methods Research but the other majors, for example, British literature, etc, but they think it doesn't influence the class teaching much because the teachers can increase their teaching experience little by little. 
TABLE III

INVESTIGATION OF THE OBJECTIVE CULTURAL CAPITAL

\begin{tabular}{|l|l|l|l|l|l|}
\hline items of questionnaire & always (\%) & often (\%) & sometimes $(\%)$ & seldom (\%) & never (\%) \\
\hline 1.often using multimedia assisted teaching & 89 & 4 & 4 & 0 \\
\hline $\begin{array}{l}\text { 2.often purchasing English teaching } \\
\text { materials }\end{array}$ & 31 & 27 & 30 & 2 \\
\hline $\begin{array}{l}\text { 3.often purchasing English newspapers } \\
\text { and English magazines }\end{array}$ & 28 & 14 & 10 & 40 \\
\hline $\begin{array}{l}\text { 4.often writing the reflective diaries about } \\
\text { teaching in the class }\end{array}$ & 8 & 5 & 62 & 20 \\
\hline $\begin{array}{l}\text { 5.often publishing the thesis about } \\
\text { English teaching }\end{array}$ & 32 & 28 & 30 & 5 \\
\hline $\begin{array}{l}\text { 6.often making the videos involved in } \\
\text { English teaching }\end{array}$ & 5 & 5 & 4 & 68 \\
\hline
\end{tabular}

Results reveal that nearly all English teachers have used multimedia assisted teaching and the teaching courseware which is downloaded from the Internet. Most teachers also said they didn't make the teaching courseware themselves because it would cost much time. Only a fraction of teachers often publish some papers about English teaching and few teachers will write their reflective diaries about teaching and teaching experience.

TABLE IV.

INVESTIGATION OF THE INSTITUTIONALIZED CULTURAL CAPITAL

\begin{tabular}{|c|c|c|c|c|c|}
\hline items of questionnaire & $\begin{array}{c}\text { always } \\
(\%)\end{array}$ & $\operatorname{often}(\%)$ & sometimes $(\%)$ & seldom $(\%)$ & $\begin{array}{r}\text { never } \\
(\%)\end{array}$ \\
\hline $\begin{array}{l}\text { 1.often having chances to attend academic meetings about } \\
\text { English teaching and engaging in the advanced studies }\end{array}$ & 15 & 13 & 25 & 37 & 10 \\
\hline 2.often trying many ways to get all kinds of credentials & 21 & 19 & 30 & 25 & 5 \\
\hline $\begin{array}{l}\text { 3.often working hard to get the higher title of a technical } \\
\text { post }\end{array}$ & 39 & 40 & 10 & 11 & 0 \\
\hline
\end{tabular}

Thirty seven percent of the teachers reveal they have few chances to attend the academic meetings about English teaching except some seminars in summer and winter vacations. It's also difficult for them to engage in the advanced studies because of the busy teaching tasks and because of the care for families. To get the high titles of the technical posts is hard for EFL teachers and many teachers will try hard to get them and get many kinds of credentials at the same time because they are useful for their self-development.

\section{Result of InVEstigation For the Cultural CAPITAl ACCUMUlation AND Suggestion}

\section{A. Accumulation of the Embodied Cultural Capital}

The questionnaire reveals that only fifty-seven percent of EFL teachers investigated know the knowledge of the pedagogy and psychology quite well; fifty-eight percent of EFL teachers investigated know English pedagogical content knowledge quite well, which will affect teachers' observation 、 judgement and understanding for their teaching and their students. Seventy-nine percent of EFL teachers investigated said they could adapt themselves to the reform of college English teaching models well and seventy-six percent of EFL teachers investigated said they had some ideas of the ways of college English teaching reform, but when asked about the detailed and specific operational approach of the teaching reform, many teachers couldn't say much about it. Because different universities have different teaching aims and the students have the diverse English competence, many EFL teachers still adopt the traditional teaching methods. Because of the lack of the teaching staff many teachers have the heavy teaching tasks to finish and at the same time are faced with great pressure of improving academic qualifications and teachers titles and finishing the scientific research tasks.

The school-based in-service training is a good way to solve this problem. Chinese universities and colleges can encourage EFL teachers to have the school-based in-service training which can become one part of the teaching tasks. It is flexible and economic to carry out and can reduce the burden of time、 expense and energy. It depends on EFL teachers' practical problems and needs and it's based on the universities where the teachers work so it's easy to manage. It can avoid the old task assignment model from the top leaders to the secondary teachers and can change the teachers' passive working attitude into the teachers' voluntary and autonomous working attitude, which can combine the whole manpower、 the material resources , the finance and information resources together and can effectively develop 、 activate and make the utmost of it. The school-based in-service training can improve the quality of education and promote EFL teachers' communication and cooperation and accelerate the development of the universities and colleges.

\section{B. Accumulation of the Objective Cultural Capital}

The questionnaire reveals ninety-three percent of the teachers investigated often use the multimedia assisted teaching, which shows the teachers can catch up with development of the society, and fifty-eight percent of the teachers investigated often purchase English teaching materials and forty-two percent of the teachers investigated often purchase English newspapers and English magazines. Only thirteen percent of the teachers say they often write the teaching 
experience summary and the teaching reflective diaries and only ten percent of the teachers investigated say they often make the videos involved in English teaching and only sixty percent of the teachers investigated say they often publish thesis about English teaching. It shows EFL teachers pay more attention to finishing their teaching tasks and pay less attention to the analysis and reflection about the class teaching. Many EFL teachers are weak in the capacity for the scientific research and it's hard for them to find the valuable research topics from their English teaching.

EFL teachers can probe many ways to enhance the teaching cooperation and improve the class teaching quality, for example, Mutual Exploration Supervision Teaching Model(2015)、CARL Model( Cooperative、Autonomous and Reflective Learning Model)(2014)、Teaching Reflection and Teaching Diaries, etc. Mutual Exploration Supervision Teaching Model proposes the process that the supervisors and the visiting teachers can guide and observe the lessons of the in-service teachers or the other teachers mutually, which can provide chances for both supervisors or the visiting teachers to find the teaching problems and improve the teaching quality. It can change FLT teachers' teaching behaviour in the classroom , increase teachers' cooperation and reduce teachers' burnout. CARL Model stands for the cooperative、 autonomous and reflective learning model, which can lead to the teachers' and students' development and improve the teaching quality. McTaggert \& Kemmis and Smith Bartlett(2002) put forward Teaching Reflective Circle, which includes five stages: planning, getting information 、analyzing , evaluating and acting. EFL teachers can use the teaching diaries as one of the ways to collect the information involved and can write the teaching diaries to reflect the class teaching.

\section{Accumulation of the Institutionalized Cultural Capital}

The questionnaire shows only twenty-eight percent of EFL teachers investigated often have the chances to attend the academic meetings and get the further professional training and it's hard for many teachers especially the young teachers to get these chances to acquire the new knowledge and new concept. It also shows forty percent of the teachers investigated will try many ways to get different credentials in order to enrich their professional quality. EFL teachers are often under great pressure because of the requirement of universities and colleges for the higher titles of the technical posts and seventy-nine percent of the teachers investigated will try their best to get them.

EFL teachers should work in the loose environment, which means the universities and colleges should develop the online classes and encourage the teachers to combine the traditional class teaching methods with the new online classes and change the old evaluation system which the teachers' scientific task comes first and the class teaching quality comes second. EFL teachers should be freed from the heavy teaching tasks and should change into students' mentors 、 helpers and counselors. EFL teachers should have more time to reflect themselves and become the research-oriented teachers and guide the whole class to have the good development.

EFL teachers can probe the ways to enhance the teachers' cooperation and facilitate the students' autonomous studying, because there is not enough academic connection and cooperation and communication among them. Many teachers just focus on their own classes too much, which will bring out the teachers' burnout if it lasts quite long time. Teachers' burnout will affect the teachers' enthusiasm and will lead to the decrease of the teaching quality. In order to avoid the teachers' burnout EFL teachers should break the current condition of the academic isolation among them and have the resource sharing and the academic cooperation. EFL teachers' mutual aid and cooperation can increase their zeal to teach well and their subjective initiative and accelerate their professional self-development.

\section{Limitations of the Research}

First, the survey is mainly based on the form of questionnaire which has not been proven to be valid or reliable, and the questionnaire is primarily descriptive. Second, the samples are mainly from two universities due to my limited resources and the number of the samples is not big enough to make the survey more reliable.

\section{REFERENCES}

[1] Brown, H.D. (2002). Principles of Language Learning and Teaching. Beijing: Foreign Language Teaching and Research Press.

[2] Chenliu. (2014). Influence of MOOC for the High Education. D. dissertation. Guangxi Normal University.

[3] Guan Lina. (2015). Research for Enhancing EFL Teachers' Self-Development in Self-Help-Explorative Model. Chongqing Second Teachers College Journal, 1, 117-119.

[4] Guan Lina. (2014). Promoting Teachers' and Students' Development in CARL in College English Teaching---in the way of Cooperation、Autonomy and Reflection, Weifang Engineering Professional School Journal, 4, 100-102.

[5] Li Jingqi. (2012). Capital and Status: Research of Social Status for Chinese Teachers in Rural Schools from the viewpoint of Sociology. Beijing: Central Compilation \& Translation Press

[6] Li qingling \& Kang zhaochun. (2010). Outlet of Chinese Intellectual from the Viewpoint of the Cultural Capital. ChangChun University of Science and Engineering, 3, 18-21.

[7] Pierre Bourdieu. (2017). Practice Theory Outline. Beijing: China Renmin University Press.

[8] Sun yuan.(2013). Research for Accumulation of the Cultural Capital among Chinese Senior High Schools under New Curriculum Reform. D. dissertation. Shanxi University.

[9] Wang nan. (2017). Research on Difference of Students' Academic Achievements from the Viewpoint of the Cultural Capital. Modern Education and Science, 12, 66-69.

[10] Zhang Zhihao. (2016). Research for Chinese Teachers Teaching Idedogical and Political Theory Course in Private University 
from the Viewpoint of the Cultural Capital. Education Modernization, 20, 69-70.

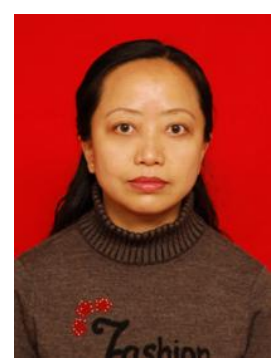

Lina Guan was born in Dazhou city, Sichuan province, China in 1972. She received her Master Degree in English Language Teaching from Western China Normal University, China in 2008.

She is currently an associate professor in the School of Foreign Language, Sichuan University of Arts and Sciences, Dazhou city, China. Her research interests include EFL acquisition and EFL teachers' development. Ms. Guan is a member of Sichuan Province Social Sciences League in China. 